\title{
Analysis the Effect of Transformational Leadership on Student Satisfaction and Its Impact on Motivation to Learn on Higher Education
}

\author{
Justine Tanuwijaya*, Deasy Aseanty, Andreas Wahyu Gunawan \\ Faculty of Economics and Business \\ Universitas Trisakti \\ Jakarta, Indonesia \\ *justine@trisakti.ac.id, deasy.aseanty@trisakti.ac.id, andreaswg@trisakti.ac.id
}

\begin{abstract}
The purpose of this study is to have better understanding the role of transformational leadership and its impact of student satisfaction and motivation to learn. This research took students as the research object. The survey questionnaire was used to obtain data. Results from a survey of 258 students were analysed using simple regression to perform statistical analysis. The scales used were transformational, student satisfaction and motivation to learn. The results show that transformational leadership positively influenced student satisfaction and motivation to learn. Moreover, motivation to learn positively affected by student satisfaction.
\end{abstract}

Keywords-motivation to learn, student satisfaction, transformational leadership

\section{INTRODUCTION}

Higher education in general need to develop innovations such as online learning to meet emerging problems and challenges due to increasing global competition, students' expectations or market changes and these challenges require education institution to engage in online learning systems to improve the current state. In addition, higher education to some extend is known as an "industry", and private universities is arguably competing with other private institutions as well as public universities. This situation is becoming critical in present days of global recession where lesser students will be welcomed in the job market. Thus, both society and universities can be cost effective having them accountable for making alumni which are transformed into and knowledge capital at the societal level. One of the best ways to become leading in academic environment is to capitalize leadership style which ensure the continuous and long-term learning process via technology.

Moreover, universities appear to be driven toward retaining their students, realizing that sustainability in lecturing will be depending upon the leadership style giving to students. The style a leader possess has become the cutting edge, which distinguishes universities apart from their competitors [1]. This will arguably affect student satisfaction and motivation to learn amongst students [2].

Effective leaders need to understand the viewpoints of their students so each leader may use appropriate leadership styles in different online learning settings to create an inclusive and an effective study environment that could enhance student satisfaction and led to motivation to learn. Although transformational leadership is supposed to be positively related to students behaviour, the prior studies appear yielded inconsistent results and showed a high variation in the relationship between transformational leadership and students behaviour. This suggests that leadership behaviours can create the right climate for managing online learning which will in turn lead to student satisfaction and motivation to learn as well. Using online learning tools, transformational leadership and elearning can be incorporated for more effective learning processes to stimulate student satisfaction in different programs, therefore, enable student's motivation to learn. As stated above, however, there seems lack of studies on examining roles of transformational leadership behaviours on student satisfaction and motivation to learn in the private education [2]. As a result, this study sought to examine the existing literature by investigating the impact transformational leadership on student satisfaction and motivation to learn in online learning at the private university.

\section{LITERATURE REVIEW}

\section{A. Transformational Leadership}

1) Definition of transformational leadership: The meaning of transformational leadership is that it is positively related to innovative students so as to produce consistent results. The aim of this study is to address an important but relatively unclear problem. This study examines the role of mediation to motivate students in which transformational leadership influences employee innovative work behavior [3]. This effect is felt by the intellectual stimulation, emotional appeal and 
inspiration of the leader and the innovation goals appear vibrant, lively, interesting and even real [4]. In transformational leaders, visionary initiatives, functional skills, individual mentoring, supportive culture and intellectual stimulation abilities can influence students to engage in innovative behavior [5].

Another definition finds that transformational leaders enhance student creativity by providing psychological empowerment, which increases employee motivation to learn [6]. Intrinsic motivation contributes to innovative work behavior because they feel controlled by their activities [7]. Most such leaders usually encourage to engage in innovative work behavior by providing a supportive environment [8]. So that transformational leaders can create a supportive workplace through inspiring, motivational and individual considerations and such a supportive environment effectively increases motivation to be involved in implementing new ideas [9]. This provides support and feedback in the search for innovative and optimal solutions [3]. By noting that innovation is quite a timeconsuming and risky endeavor therefore leaders must know the right time and procedure to provide the necessary support to improve the innovative performance of followers [10]. suggested that transformational leaders must be open, experimenting and dare to take risks, resulting in innovative work behavior in the context of an organization [11]. Here are some dimensions of transformational leadership.

\section{2) Several dimensions of transformational leadership:}

a) Idealized Influence (II): Transformational leaders are able to make their subordinates follow them because they think that transformational leaders can be used as role models or good figures for their subordinates. A leader is someone who is respected, emulated, and can be trusted. His subordinates aspire to be like him, his subordinates imitate his behavior, and transformational leaders are considered by his subordinates to have good advantages and abilities.

b) Inspirational Motivation (IM): Transformational leaders always encourage their subordinates to have a vision for the future, have good communication, and are highly committed to their work. This can happen because transformational leaders always motivate and provide examples to their subordinates by paying attention to their work; build morale, and provide a sense of enthusiasm and optimism.

c) Intellectual Stimulation (IS): Transformational leaders encourage their subordinates to try to be innovative and creative by actively asking about their assumptions, exploring pre-existing problems, and updating old approaches with newer ones.

d) Individual Consideration (IC): Transformational leaders pay more attention to each follower individually to achieve and develop by acting as a coach or mentor, so that followers will develop their potential to a much higher level. The main requirement for this component is a conducive climate.
From these four dimensions, an inspiring environment is created in carrying out challenging tasks and making employee work more interesting and fun [12]. This is what makes students more creative and can find innovative results [11]. From this, Student Satisfaction was created in relation to work and education.

\section{B. Student Satisfaction}

1) Definition of student satisfaction: The definition of student satisfaction is to consider student satisfaction as one of the main elements to ensure quality assurance and improvement of their programs [13]. Student satisfaction is an important concept in the university field because it is a measure often used in ranking and league tables which are usually used as a measure of the reputation of a university [14]. Universities can also benefit from student satisfaction with higher student retention rates and reduced friction and as a result, a positive influence on student numbers [15]. In this case also has an impact on Student Satisfaction.

2) Impact of student satisfaction: The impact of student satisfaction is that on the application of students who are at home to get a bachelor's degree using the data in this study they must understand how the quality of market signals in higher education works [16]. Despite the substantial research attention to academic experience and student satisfaction, most of the studies conducted have focused on undergraduate student satisfaction, while no research has focused on graduate student satisfaction [16]. Likewise, academic staff is not only the main point of contact for academic issues, but also for non-academic issues. Staff enthusiasm and its influence in creating a supportive learning environment also has a positive impact on student satisfaction [17].

In this regard, it affects the management of facilities that play an important role in achieving university goals by providing students and employees with an effective infrastructure as the basis for university functions [18]. further articulate this point by stating that their research findings indicate that factors associated with research and teaching spaces have the greatest impact on overall satisfaction for both student and staff groups as an improvement in the quality of these spaces [18]. Will directly assist staff and students in achieving their goals. In addition, university facilities have an impact on students' university choice [19] because service quality has an impact on student learning [20].

On the other hand, they also determined that computer access on campus did not affect student satisfaction [21], but unsuitable facilities have been found to damage and decrease student motivation [22]. In addition, the organization and management of the course have an effect on the quality of services provided to students. As a result, it affects student satisfaction [23]. That students have a higher level of satisfaction than students on the placement of supporting elements [24]. concluded that student learning experiences increase when assessment expectations are clearly stated and 
prompt feedback is given [25]. From student satisfaction, motivation to learn is created.

\section{Motivation to Learn}

1) Definition of motivation to learn: The definition of motivation to learn is assistance to students who are learning to change their behavior, in ways or elements that affect this behavior [26]. In addition, motivation to learn is a power from within the human mind such as curiosity, a desire that is expected, and high aspirations, so that it can make someone learn [27]. Motivation to learn is needed to increase enthusiasm, make feelings better, and foster a desire to seek knowledge or information [28]. When viewed from the theories related to motivation to learn, it can be formulated the notion that motivation is not an output or result, but a process. If there is the right motivation, the learning outcomes will be maximized. If there is good motivation, learning outcomes will be good. So that employees can learn well, motivation to learn is needed.

To choose student motivation to be active in learning as a mediating factor and task complexity and innovation climate as a moderating factor lies in the idea of integrating multi-level factors for a holistic understanding of employee innovation [29]. Motivation to learn as a mediating factor of innovative work behavior It is said that "a continuous commitment to learning is central to innovation" [30]. Students to be involved or not involved in innovative behavior are influenced by their motivation to learn [7]. Motivation to learn refers to the desire of students to learn new knowledge or insights that encourage individuals to be creative and innovative in their work [31].

Individuals with strong motivation to learn see difficult tasks as opportunities for growth and development [32]. A meta-analytic study also provides strong evidence that motivation to learn is positively correlated with learning outcomes for declarative knowledge and skill acquisition [33]. The conceptual framework can be seen in figure 1 .

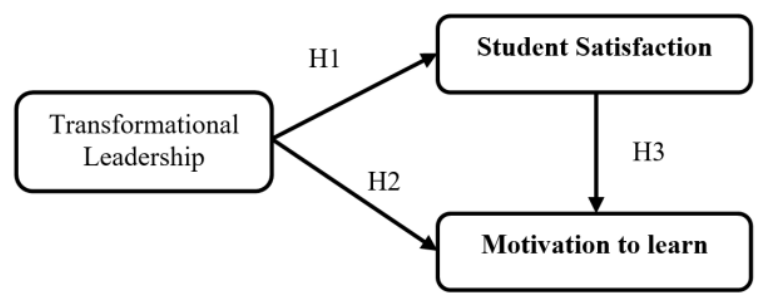

Fig. 1. Conceptual framework

\section{HYPOTHESIS DEVELOPMENT}

Transformational leaders are ready to be leaders and give important tasks to student satisfaction, it can be seen from the complex student satisfaction interactions that give rise to feedback from the individual level factors themselves, besides that organizations must facilitate with their own initiative in managing the organization so as to generate motivation in students themselves [34].

\section{A. H1: There is a Positive Impact of Transformational Leadership to Student Satisfaction}

Transformational leadership is described as a process in which leaders play ideal role models, stimulate and encourage innovative behavior, provide inspiring motivation and are involved in supporting and guiding followers to achieve a common vision and goals so that it has a positive effect on student satisfaction [35].

\section{B. H2: There is a Positive Impact of Transformational Leadership to Motivation to Learn}

The relationship between Transformational Leadership to Motivation to learn has the potential to improve overall student performance so that they become motivated [13].

\section{H3: There is a Positive Impact of Student Satisfaction to Motivation to Learn}

Research assumes that Student Satisfaction affects innovative Motivation to learn, depending on individual interactions, to deal with other situational and contextual factors [36].

\section{RESEARCH METHODOLOGY}

\section{A. Methods}

Quantitative approach and survey methodology were employed to collect data. The questionnaire was distributed to the students of four level degree program of Faculty of Economics and Business, Universitas Trisakti, included diploma, bachelor, master and doctoral degree through google form. Convenience sampling was used to distribute the questionnaires to the targeted sample. Of the distributed questionnaires, 258 were returned and all of them were usable.

\section{B. Measures}

A survey questionnaire was developed to collect the required data for the current study. The questionnaire contained 33 items for measuring the research variables: 20 items to measure transformational leadership adopted from Podsakoff et al [37], 9 items to measure student satisfaction adopted from Dziuban et al., [38] and 4 items to measure motivation to learn adopted from Noe and Schmitt [39]. Respondents were asked to indicate their agreement or disagreement with the statements provided using a five-point Likert scale where 1 indicated strongly disagree and 5 indicated strongly agree.

\section{Validity and Reliability}

All items of questionnaires were valid, since their factor loading were more than 0.35 . We know that loading factor for sample size $250=0.35$ [40]. 
Reliability of the constructs was tested using Cronbach's Alpha. The Cronbach's Alpha values were 0.936 for transformational leadership, 0.923 for student satisfaction and
0.84 for motivation to learn. These values indicated acceptable internal consistency with $\alpha>0.70$ for the three constructs [40]. The validity test can be seen in table 1 .

TABLE I. VALIDITY TEST

\begin{tabular}{|c|c|c|c|c|}
\hline & & FL1 & FL2 & FL3 \\
\hline TL1 & $\begin{array}{l}\text { Idealized Influence } \\
\text { My lecturer instills pride in me when associated with others }\end{array}$ & 0.638 & & \\
\hline TL2 & My lecturer talks about my most important values and beliefs & 0.690 & & \\
\hline TL3 & My lecturer specificies the importance of a strong sense of purpose & 0.642 & & \\
\hline TL4 & My lecturer convinces me to go beyond self-interest for the good of the group & 0.492 & & \\
\hline TL5 & My lecturer acts in ways that build others' respect for me & 0.644 & & \\
\hline TL6 & $\begin{array}{l}\text { Inspirational Motivation } \\
\text { My lecturer considers moral and ethical consequences of decisions }\end{array}$ & 0.620 & & \\
\hline TL7 & My lectuter displays a sense of power and confidence & 0.727 & & \\
\hline TL8 & My lecturer emphasizes the importance of having a collective sense of mission & 0.756 & & \\
\hline TL9 & My lecturer talks optimistically about future & 0.731 & & \\
\hline TL10 & My lecturer talks enthusiastically about what needs to be established & 0.682 & & \\
\hline TL11 & $\begin{array}{l}\text { Intellectual Stimulation } \\
\text { My lecturer articulates a compellrng vision of future }\end{array}$ & 0.674 & & \\
\hline TL12 & My lecturer expresses confidence through his/her behavios that goals will be achieved & 0.679 & & \\
\hline TL13 & My lecturer re-examines the critical assumptions and questions whatever they are appropriate & 0.712 & & \\
\hline TL14 & My lecturer seeks differing perspective when solving problems & 0.704 & & \\
\hline TL15 & My lecturer gets others to look at problems from many different angles & 0.611 & & \\
\hline TL16 & $\begin{array}{l}\text { Individual Consideration } \\
\text { My lecturer suggests new ways of looking at how to complete assignments }\end{array}$ & 0.680 & & \\
\hline TL17 & My lecturer spends time coaching, teaching and mentoring his/her followers & 0.699 & & \\
\hline TL18 & My lecturer treats others as individuals rather than just as a member of a group & 0.716 & & \\
\hline TL19 & My lecturer considers an individual as having different needs, abilities and aspirations from others & 0.697 & & \\
\hline TL20 & My lecturer helps others to develop their strengths & 0.725 & & \\
\hline SS1 & Generally, I am more engaged in my online learning & & 0.701 & \\
\hline SS2 & I have more opportunities to reflect on what I have learned in online learning & & 0.841 & \\
\hline SS3 & Online learning helps me understand course material & & 0.851 & \\
\hline SS4 & There are more opportunities to collaborate with other students in an online learning & & 0.767 & \\
\hline SS5 & My online experience has increased my opportunity to access and use information & & 0.719 & \\
\hline SS6 & I am more likely to ask questions in online learning & & 0.756 & \\
\hline SS7 & Generally, I understand course requirements better in an online learning & & 0.847 & \\
\hline SS8 & Because of online learning, I am more likely to get a degree & & 0.739 & \\
\hline SS9 & I can manage my own learning better in online learning & & 0.860 & \\
\hline ML1 & I am motivated to learn the skills emphasized in the job & & & 0.810 \\
\hline ML2 & I will try to learn as much as I can from my job & & & 0.852 \\
\hline ML3 & I am willing to exert considerable effort in my job in order to improve my skills & & & 0.853 \\
\hline ML & I often look for opportunities ro develop new skills and knowledge & & & 0.777 \\
\hline
\end{tabular}

\section{RESULTS}

Of 258 respondents participated in this survey: $53.9 \%$ are female; $76.4 \%$ are bachelor's degree; $50 \%$ between $20-30$ years old; $84.5 \%$ are single; $65.1 \%$ are unemployed and $59.7 \%$ of them have $1-3$ years length of study.

\section{A. Descriptive Statistics}

By using SPSS 25, total mean of transformational leadership $=4.279$. The leadership style possessed by the lecturer is felt strong. Students argue that the leadership of a lecturer is critical with assumptions and questions, provides good guidance and learning and helps students to develop their abilities.
Variable student satisfaction has total mean 3.478. There is a satisfaction that is felt enough by students. Students are more actively involved in asking questions in learning activities. In addition, they feel that they have a big enough obsession to get their degree on time.

Total mean of motivation to learn $=4.322$. Students have high motivation to learn. Students are willing to put forth maximum effort in learning in order to improve skills. Students are always looking for opportunities to seek new knowledge, the desire to repeat lessons in learning process is strong.

\section{B. Hypotheses Testing}

To test the study hypotheses, linear regression analysis was used. Determination coefficient test can be seen in table 2 . 
TABLE II. DETERMINATION COEFFICIENT TEST

\begin{tabular}{|l|l|l|l|l|}
\hline & R & R Square & $\begin{array}{c}\text { Adjusted } \\
\text { R Square }\end{array}$ & $\begin{array}{c}\text { Std Error of the } \\
\text { Estimate }\end{array}$ \\
\hline TL and SS & $.391^{\mathrm{a}}$ & .153 & .150 & 7.13887 \\
\hline TL and MTL & $.613^{\mathrm{a}}$ & .376 & .374 & 1.76826 \\
\hline SS and MTL & $.384^{\mathrm{a}}$ & .148 & .144 & 2.06665 \\
\hline
\end{tabular}

TABLE III. LINEAR REGRESSION ANALYSIS FOR THE EFFECT OF TRANSFORMATIONAL LEADERSHIP TO STUDENT SATISFACTION AND MOTIVATION TO LEARN

\begin{tabular}{|l|l|l|l|}
\hline & \multicolumn{1}{|c|}{ Beta } & sig & \multicolumn{1}{c|}{ Decision } \\
\hline H1 $:$ TL $\rightarrow$ SS & 0.391 & 0.000 & Supported \\
\hline H2 $:$ TL $-\rightarrow$ MTL & 0.748 & 0.000 & Supported \\
\hline H3 : SS $\rightarrow$ MTL & 0.384 & 0.000 & Supported \\
\hline
\end{tabular}

Source: SPSS 25

As shown in Table 3, the effect of transformational leadership on student satisfaction and motivation to learn and also the effect of student's satisfaction on motivation to learn were positive and significant; therefore all of hypotheses were supported.

\section{DISCUSSION}

The current study examined the effect of transformational on student satisfaction and motivation to learn and also the effect of student satisfaction on motivation to learn. The study results proved that transformational leadership positively and significantly effected on student satisfaction and motivation to learn. These results are in line with some previous studies [4144].

Another finding of the current study also proved that student's satisfaction positively and significantly effected on motivation to learn. This result is also consistent with previous studies [45-47].

\section{CONCLUSION}

This research was conducted for all degrees in Faculty of Economics and Business, Universitas Trisakti to examine the effect of transformational leadership on student satisfaction and motivation to learn in online learning. The findings indicated significant effect of transformational leadership on student satisfaction and motivation to learn. The result also revealed the positive and significant effect of student satisfaction on motivation to learn.

\section{VIII.PRACTICAL IMPLICATIONS}

With student satisfaction and high learning motivation, the quality of learning outcomes will increase. Thus, it can be said that quality of the output has also improved. The increased quality of output has an effect on the image of higher education from society thus it will eventually increase the number of students applying for studying, improve university ranking, there will be a lot of word of mouth so that it can affect the number of new students.

\section{LIMITATIONS AND RECOMMENDATIONS FOR FUTURE RESEARCH}

This research has some limitations that could be considered in future studies. First, the use of convenience sampling limits the generalizability of the results. Second, the number of research variables in this study is only limited to transformational leadership, student satisfaction and motivation to learn. Third, relatively small number of samples since the sample size was only 258 .

Future studies are recommended with a sample covering most universities in Jakarta at least that have the same accreditation as Universitas Trisakti. In addition, future studies could add other research variables such as student performance impact, actual use of online learning, learning climate, etc. It is also suggested to increase the number of samples by distributing the questionnaires to a wider range of students.

\section{REFERENCES}

[1] S. Arif, M. Ilyas, and A. Hameed, "Student satisfaction and impact of leadership in private universities," TQM J., 2013.

[2] A. Aldholay, Z. Abdullah, O. Isaac, and A.M. Mutahar, "Perspective of Yemeni students on use of online learning," Inf. Technol. People, 2019.

[3] H.H.M. Tse, M.L. To, and W.C.K. Chiu, "When and why does transformational leadership influence employee creativity? The roles of personal control and creative personality," Hum. Resour. Manage., vol. 57, no. 1, pp. 145-157, 2018.

[4] A. Zuraik and L. Kelly, "The role of CEO transformational leadership and innovation climate in exploration and exploitation,” Eur. J. Innov. Manag., 2019.

[5] B. Afsar, Y.F. Badir, and B. Bin Saeed, "Transformational leadership and innovative work behavior," Ind. Manag. Data Syst., 2014.

[6] X. Zhang and K.M. Bartol, "The influence of creative process engagement on employee creative performance and overall job performance: A curvilinear assessment.," J. Appl. Psychol., vol. 95, no. 5, p. 862, 2010.

[7] M.-C. Yu, X.-T. Zheng, G. G. Wang, Y. Dai, and B. Yan, "When does motivation to learn reduce innovative behavior? An examination of mediated-moderation model,” Balt. J. Manag., 2018.

[8] T.C. Bednall, A.E. Rafferty, H. Shipton, K. Sanders, and C.J. Jackson, "Innovative behaviour: how much transformational leadership do you need?," Br. J. Manag., vol. 29, no. 4, pp. 796-816, 2018.

[9] M. Masood and B. Afsar, "Transformational leadership and innovative work behavior among nursing staff," Nurs. Inq., vol. 24 , no. 4, p. e12188, 2017.

[10] Y. Du, P. H. Kim, and H.E. Aldrich, "Hybrid strategies, dysfunctional competition, and new venture performance in transition economies," Manag. Organ. Rev., vol. 12, no. 3, pp. 469-501, 2016.

[11] X. Ma and W. Jiang, "Transformational leadership, transactional leadership, and employee creativity in entrepreneurial firms," J. Appl. Behav. Sci., vol. 54, no. 3, pp. 302-324, 2018.

[12] J.H. Golden III and M. Shriner, "Examining relationships between transformational leadership and employee creative performance: The moderator effects of organizational culture," J. Creat. Behav., vol. 53, no. 3, pp. 363-376, 2019.

[13] S.K. Parahoo, M.I. Santally, Y. Rajabalee, and H.L. Harvey, "Designing a predictive model of student satisfaction in online learning," J. Mark. High. Educ., vol. 26, no. 1, pp. 1-19, 2016.

[14] S. Gibbons, E. Neumayer, and R. Perkins, "Student satisfaction, league tables and university applications: Evidence from Britain," Econ. Educ. Rev., vol. 48, pp. 148-164, 2015. 
[15] J. Douglas, A. Douglas, and B. Barnes, "Measuring student satisfaction at a UK university," Qual. Assur. Educ., 2006.

[16] P. Lenton, "Determining student satisfaction: An economic analysis of the National Student Survey," Econ. Educ. Rev., vol. 47, pp. 118-127, 2015.

[17] R. Arambewela and J. Hall, "An empirical model of international student satisfaction,” Asia Pacific J. Mark. Logist., 2009.

[18] S. Kärnä and P. Julin, "A framework for measuring student and staff satisfaction with university campus facilities," Qual. Assur. Educ., 2015.

[19] I.F. Price, F. Matzdorf, L. Smith, and H. Agahi, "The impact of facilities on student choice of university," Facilities, 2003.

[20] C.K. Tanner, "Effects of school design on student outcomes," J. Educ. Adm., 2009.

[21] T.-E. S. Hanssen and G. Solvoll, "The importance of university facilities for student satisfaction at a Norwegian University," Facilities, 2015.

[22] A. Hassanbeigi and J. Askari, "A study of the most important risk factors of motivational deficiencies in university students," ProcediaSocial Behav. Sci., vol. 5, pp. 1972-1976, 2010.

[23] J. Johnston, J. Killion, and J. Oomen, "Student satisfaction in the virtual classroom," Internet J. Allied Heal. Sci. Pract., vol. 3, no. 2, p. 6, 2005.

[24] F. O'Driscoll, "What matters most: An exploratory multivariate study of satisfaction among first year hotel/hospitality management students," Qual. Assur. Educ., 2012.

[25] S. Smyth, C. Houghton, A. Cooney, and D. Casey, "Students' experiences of blended learning across a range of postgraduate programmes," Nurse Educ. Today, vol. 32, no. 4, pp. 464-468, 2012.

[26] H.B.Uno, Teori Motivasi dan Pengukurannya. Jakarta: PT. Bumi Aksara, 2012.

[27] Dimyati and Mudjiono, Belajar dan Pembelajaran. Jakarta: PT Rineke Cipta, 2006.

[28] A.M, Sardiman, Interaksi dan Motivasi Belajar Mengajar. Jakarta: PT. Raja Grafindo Persada, 2010.

[29] B. Afsar and M. Masood, "Transformational leadership, creative selfefficacy, trust in supervisor, uncertainty avoidance, and innovative work behavior of nurses", The Journal of Applied Behavioral Science, vol. 54 no. 1, pp. 36-61, 2018,

[30] J. Rhee, T. Park, and D.H. Lee, "Drivers of innovativeness and performance for innovative SMEs in South Korea: Mediation of learning orientation," Technovation, vol. 30, no. 1, pp. 65-75, 2010.

[31] Y. Gong, J.-C. Huang, and J.-L. Farh, "Employee learning orientation, transformational leadership, and employee creativity: The mediating role of employee creative self-efficacy," Acad. Manag. J., vol. 52, no. 4, pp. 765-778, 2009

[32] S.C. Payne, S.S. Youngcourt, and J.M. Beaubien, "A meta-analytic examination of the goal orientation nomological net.," J. Appl. Psychol., vol. 92 , no. 1, p. 128, 2007.
[33] J.A. Colquitt, J.A. LePine, and R.A. Noe, "Toward an integrative theory of training motivation: a meta-analytic path analysis of 20 years of research.," J. Appl. Psychol., vol. 85, no. 5, p. 678, 2000

[34] L. Yuan, L. Zhang, and Y. Tu, "When a leader is seen as too humble: a curvilinear mediation model linking leader humility to employee creative process engagement", Leadership \& Organization Development Journal, vol. 39, no. 4, pp. 468-481, 2018.

[35] T.S. Suifan, A.B. Abdallah, and M. Al Janini, "The impact of transformational leadership on employees' creativity: The mediating role of perceived organizational support," Management Research Review, vol. 41, no. 1, pp. 113-132, 2018.

[36] G. Koseoglu, Y. Liu, and C. E. Shalley, "Working with creative leaders: Exploring the relationship between supervisors' and subordinates' creativity," Leadersh. Q., vol. 28, no. 6, pp. 798-811, 2017.

[37] P.M. Podsakoff, S.B. MacKenzie, and W.H. Bommer, "Transformational leader behaviors and substitutes for leadership as determinants of employee satisfaction, commitment, trust, and organizational citizenship behaviors," J. Manage., vol. 22, no. 2, pp. 259-298, 1996

[38] C. Dziuban, P. Moskal, J. Brophy, and P. Shea, "Student satisfaction with asynchronous learning.," J. Asynchronous Learn. Networks, vol. 11 , no. 1, pp. 87-95, 2007

[39] R.A. Noe and N. Schmitt, “The influence of trainee attitudes on training effectiveness: Test of a model," Pers. Psychol., vol. 39, no. 3, pp. 497523, 1986.

[40] Hair, Multivariate Analysis, $7^{\text {th }}$ edition. Pearson, 2010.

[41] A. Rezvani, L. Dong, and P. Khosravi, "Promoting the continuing usage of strategic information systems: The role of supervisory leadership in the successful implementation of enterprise systems," Int. J. Inf. Manage., vol. 37, no. 5, pp. 417-430, 2017.

[42] F. Eriksson and C. Jonsson, Transformational leadership's effect on motivation and trust: A case study of Volvo sales region EMEA. 2016.

[43] S. Andriani, N. Kesumawati, and M. Kristiawan, "The influence of the transformational leadership and work motivation on teachers performance,” Int. J. Sci. Technol. Res., vol. 7, no. 7, pp. 19-29, 2018.

[44] J. Shabazz, "Transformational Leadership: Motivating Students to Learn," 2020.

[45] N. Hasan, S.A. Malik, and M.M. Khan, "Measuring relationship between students' satisfaction and motivation in secondary schools of Pakistan,” Middle-East J. Sci. Res., vol. 18, no. 7, pp. 907-915, 2013.

[46] Y. Stukalina, "Identifying Predictors of Student Satisfaction and Student Motivation in the Framework of Assuring Quality in the Delivery of Higher Education,” Business, Manag. Educ., vol. 12, no. 1, pp. 127-137, 2014.

[47] H. Snopce and S. Alija, "Student Satisfaction, Needs, Learning Outcome and Motivation: A Case Study Approach at A See-University," Eurasia Proc. Educ. Soc. Sci., vol. 10, pp. 197-202, 2018. 